\title{
Instructional Supervision Towards Teacher's Quality of YIK Religious Secondary Schools in Kelantan, Malaysia
}

\author{
Nasuha binti Haji Musa ${ }^{1 *}$ \\ ${ }^{1}$ Universiti Utara Malaysia, Malaysia \\ *e-mail: nasuhamusa@gmail.com
}

\begin{abstract}
The Malaysian Education Blueprint (MEB) 2013-2025 emphasized on principals' supervisory practices and teachers' quality to enhance 21st-century international quality education. The lack of professional training for principals and the decline of teacher's quality according to Yayasan Islam Kelantan (YIK) report (YIK, 2017) have affected the government's aspirations. This problem requires a solution because the instructional supervision is a catalyst of teachers' professional values and quality. Meanwhile, teachers' quality is related to teaching professionalism practices, knowledge, understanding as well as teaching and learning skills. This study is essential for principals' instructional supervision improvement and enhancing teachers' quality. A quantitative, cross-sectional survey approach was adopted using a standardized three-section questionnaire comprising Section A: Respondents' Personal and Professional Backgrounds, Section B: Instructional Supervision and Section C: Teachers' Quality. The study sample comprised 360 teachers in YIK Religious Secondary Schools. A descriptive and inferential data analysis was generated using the Statistical Package for Social Science (SPSS) 20 Version. The improved quality among teachers was the result of holistic supervisory practices of principals namely, directive guidance, collective development, professional development, curriculum development and action research guidance. Thus, it is significant that principals understand the practical dimensions of supervision in order to improve teachers' quality in YIK Religious Secondary Schools in Kelantan. It is recommended that YIK focuses on instructional supervision practices to produce quality teachers as the principals' instructional supervision is highly potential catalysts for quality teachers.
\end{abstract}

Keywords:

Instructional Supervision; Teacher's Quality; Principals' Professional Training; Educational Transformation, World Standard Education. 


\begin{abstract}
ABSTRAK
Malaysian Education Blueprint (MEB) 2013-2025 menekankan pada praktik pengawasan kepala sekolah dan kualitas guru dalam meningkatkan kualitas pendidikan Internasional pada abad ke-21. Minimnya pelatihan profesional bagi kepala sekolah dan menurunnya kualitas guru sebagaimana laporan Yayasan Islan Kelantan (YIK) (YIK, 2017) telah mempengaruhi aspirasi pemerintah. Masalah ini memerlukan penyelesaian karena supervisi pembelajaran merupakan katalisator nilai dan kualitas profesioanlisme guru. Sementara itu, kualitas guru berkaitan dengan profesionalisme mengajar, pengeteahuan, pemahaman yang serta keterampilan mengajar. Penelitian ini penting untuk meningkatkan supervisi instuksional kepala sekolah dan meningkatkan kualitas guru. Pendekatan kuantitatif cross-sectional survey diadopsi dengan menggunakan tiga kuesioner standar. Bagian A : Latar belakang Pribadi dan Profesional, Bagian B : Pengawasan Instruksional dan Bagian $C$ : Kualitas Guru. Sampel penelitian adalah 360 guru di Sekolah Menengah Agama YIK. Data deskriptif dan inferensial dianalisis dengan menggunakan SPSS 20. Peningkatan kualitas guru merupakah hasil dari praktik pembinaan holistik kepala sekolah yaitu bimbingan direktif, pengembangan profesionalitas, pengembangan kurikulum dan bimbingan penelitian tindakan. Dengan demikian, penting bagi kepala sekolah untuk memahami dimensi praktis supervisi guna meningkatkan kualitas guru Sekolah Menengah Agama YIK di Kelantan. Disarankan agar YIK fokus pada praktik supervisi instuksional untuk menghasilkan guru yang berkualitas karena supervisi instruksional kepala sekolah sangat berpotensi menjadi katalisator bagi guru yang berkualitas.
\end{abstract}

Kata Kunci:

Supervisi Instruksional; Kualitas Guru; Prinsip Pelatihan Profesionalisme; Transformasi Pendidikan; Taraf Pendidikan Dunia.

\title{
1. Introduction
}

The focus of this study is the improvement of Yayasan Islam Kelantan (YIK) Religious Secondary Schools' teachers' quality and principals' supervisory practice because teachers' quality has declined and there was lack of professional training for principals according to YIK's report (YIK, 2017) and it has affected the educational transformation. Meanwhile, The Malaysian Government through the Ministry of Education (MOE) is continuously committed to the Malaysian education development. Quality and world standard education is the main agenda of MOE within these two decades (2013-2025) to generate the progressive, quality and competitive human resources (Malaysian Education Blueprint (MEB) 2013-2025). As such, this study is implemented to explore the implementation of a feasibility supervisory practice to review its influence on the quality of the YIK Religious Secondary Schools' teachers.

As the intended human resources is in line with the development of the $21^{\text {st }}$-century education is the world standard ones, teachers who play roles to form the intended people absolutely should consist of the high quality teachers. Hence, the Malaysian Government has developed various initiatives to improve the quality of teachers throughout their teaching services. In addition, the competency of the school leadership is strengthened through the continuation of the competency qualification including The National Professional Qualification for Educational Leaders (NPQEL) 
and Residency and Immersion Program (PRIME) (MEB 2013-2025 Annual Report, 2017). In this regard, school principals' supervisory practice techniques should be implemented in a standard, systematic and holistic form. However, the empirical studies that have been implemented showed that the implementation practices of the instructional supervision were still unstandardized among the school principals (Nurahimah \& Rafisah, 2010; Arsaythamby \& Mary, 2013; Weerakoon, 2017).

Therefore, researcher has chosen to explore the school principals' instructional supervision to enhance the quality of the teacher as their instructional supervision has significant linkages with the quality of teachers according to Nurahimah and Rafisah (2010). Quality of the teacher has been selected based on the aspiration of the Malaysian Education Blueprint (MEB) 2013-2025 which targets Malaysian education system in the world's top third place by the year 2025. This factor was also based on the teaching and learning performance level as reported by YIK is at the 'Hope' level (60\%-79\%) (YIK, 2017).

Hence, the achievement of the teaching of YIK Religious Secondary Schools has yet to be able to rival. The performance of the teacher's teaching level did not occur any increase from the year 2013 until the year 2017 (YIK, 2017). In the year 2014, percentage of the performance of teachers' teaching declined from $64.40 \%$ to $62.31 \%$ in 2015 at $2.09 \%$. The decline in the performance of the teachers continued to occur at $62.31 \%$ in 2015 to $61.78 \%$ in 2016 where the achievement declined by $0.53 \%$. Consequently, declining performance decreased by $0.78 \%$, which was $61.78 \%$ in 2016 to $61.00 \%$ in 2017 . Table 1 shows a detailed percentage of teaching achievement of YIK's teacher starting the year 2013 to the year 2017.

Table 1. YIK Religious Secondary School Teachers' Teaching Performance Year 2013-2017

\begin{tabular}{cccccc}
\hline Year & $\mathbf{2 0 1 3}$ & $\mathbf{2 0 1 4}$ & $\mathbf{2 0 1 5}$ & $\mathbf{2 0 1 6}$ & $\mathbf{2 0 1 7}$ \\
\hline Percentage of Performance & $62.70 \%$ & $64.40 \%$ & $62.31 \%$ & $61.78 \%$ & $61.00 \%$ \\
\hline Level of Performance & Hope & Hope & Hope & Hope & Hope \\
\hline
\end{tabular}

(Source; YIK, 2017)

In this regard, twelve criteria that are reviewed in teaching and learning assessment include; students' involvement in learning, students' mastery learning, students' work, teachers' teaching plan and preparation, teachers' delivery methods, teachers' communication skills, educational tools and resources, students' assessment, advocacy techniques, teachers' mastery content, class management and teacher's professionalism based on the highest score is 6 and lowest score is 1 . Table 2 shows the achievement of teacher teaching performance based on the particular assessment:

Table 2. Teaching Achievement of YIK Religious Secondary Schools In Kelantan Based on Score And Percentage of Marks

\begin{tabular}{lccl}
\hline \multicolumn{1}{c}{ Level } & Score & Percentage & \multicolumn{1}{c}{ Description } \\
\hline Excellent & 6 & $90-100$ & $\begin{array}{l}\text { Overall strength is very clear and has value-added, recognition } \\
\text { and can be an example of other individuals/schools. }\end{array}$ \\
Good & 5 & $80-89$ & Overall strength is very clear. \\
Hope & 4 & $60-79$ & Many strengths exceed the minimum requirements \\
Satisfying & 3 & $40-59$ & Many strengths meet the minimum requirements \\
Weak & 2 & $20-39$ & Less shortcomings exceed the minimum requirements
\end{tabular}


Very Weak $\quad 1 \quad 00-19 \quad$ Many shortcomings require corrective action immediately.

In the view of the teachers' quality, there was a negative implication to the MOE ability as well as state educational management and YIK. Therefore, the development of the supervisory influence on quality of teachers at YIK Religious Secondary Schools requires a comprehensive survey to be reviewed to ensure that the education sector is capable of continuing its hard work to improve the quality of education. This achievement was very alarming as MOE has implemented various initiatives to improve the quality of the teachers.

Leadership development skills in the YIK education system is also at an alarming level as there has not been any YIK Religious Secondary Schools principals who had the opportunity to follow the NPQEL programme or obtained NPQEL certificate (YIK, 2018). Hence, the study was carried out to review the implementation of a feasibility supervision practice to improve the quality of teachers at YIK Religious Secondary Schools. At the same time, it was able to mobilize and move the school members to develop the school and improve the quality of teaching and learning (TNL) performance of the teachers.

Based on the techniques of school principals' instructional supervision practices, this study is implemented to explore the implementation of a feasibility supervisory practice to review its influence on the quality of the Yayasan Islam Kelantan (YIK) Religious Secondary Schools' teachers. The purpose of the study was to clarify the influence of the instructional supervision on the quality of YIK Religious Secondary Schools' teachers. The objectives of this study are; explaining the supervisory level, explaining the quality level of teachers and explaining significant influence of instructional supervision towards the teachers' quality.

In reviewing the studies regarding instructional supervision, there are different dimensions of instructional supervision studies based on the different views of researchers. Thus, among them focused on the conditions of supervision while others focused on methods, prospects and instructional supervision problem solving. While some researchers tried to find out the relationship between instructional supervision and teachers' competency. In fact, the researchers from the developed states like United States of America, Britain, Norway, Germany and Sweden have been introduced the models of instructional supervision which show the rapid progress and development of education system in their countries.

Meanwhile, The Malaysian educational transformation agenda through Malaysian Education Development Blueprint (MEB) 2013-2025 among others is improving the quality of the teachers by improving the educational system. It is a very important factor for improving the quality of teachers based on the studies conducted by Tesfaw and Hofman (2012), Mohd Izham et al., (2013), Dangara (2015), Anike (2015), Gloria et al., (2016), Weerakoon (2017), Grace et al., (2018), Mwainiki \& Guantai (2018), Malunda et al., (2018), Esia and Baffoe (2018). The instructional supervision enhances the teachers' teaching quality by improving the teaching skills and increasing the student's academic achievement (Samoei, 2014) because it helps teachers to identify the advantages and weaknesses of the teaching and learning practices performance (Arsaythamby \& Mary, 2013). 
However, Norlela and Mohd (2015) suggested that the role of management of education sector is strengthened and the empowerment is translated through organizing seminars, effective instructional supervision courses and workshops (Gloria et al., 2016) including collegial supervisory approaches and techniques (Samoei, 2014; Malunda et al., 2016). The recommendation is based on the outcome of the study indicating that the effective instructional supervision will assist teachers to make improvements in their teaching (Lilia Halim, Nor Aisyah Buang \& Subahan, 2010; Samoei, 2014; Norlela \& Mohd , 2015; Malunda et al., 2016).

The educational management sectors are also recommended to evaluate the audit of school principal to ensure an efficient and effective implementation of instructional supervision. The proposal was raised by Dangara (2015) and Malunda et al., (2016) in their studies on the supervision of pedagogical practices. Accordingly, the school principals' supervision was able to resolve educational issues especially the problems regarding teachers. Nevertheless, the standardization of the dimension practice has not been achieved. The inconsistencies are caused by world coverage, the needs and interests of the studies.

In other side, Mohammad, Miss Asthma and Zamri (2014) showed in their studies that there was a significant relationship between the quality of teachers and students' interest and achievement (Goe, 2007). The study also pointed out that the teachers are the most influential individuals in increasing students' achievement. There are many among the researchers that emphasized the need for continuous training and guidance organized for teachers throughout their educational services. Among them were Nur Mustafa and Norasmah (2011), Muhammad Faizal and Abd Khalil (2015), Dangara (2015), Gloria et al., (2016), Esia and Baffoe (2018) and Mwainiki and Guantai (2018). Nur Mustafa and Norasmah (2011) suggested that approaches or programmes should be implemented by MOE or the government through the education sectors (Anike, 2015) to diversify and strengthen the training programmes in service to give significant impact in enhancing teachers' motivation (Esia \& Baffoe, 2018) and working performance (Nur Mustafa \& Norasmah, 2011) as a catalyst for the professional value development of teachers (Nur Mustafa \& Norasmah, 2011; Esia \& Baffoe, 2018).

According to Sullivan and Glanz (2008), the instructional supervision is able to solve education issues. The findings of this study will be made a guide to school principals especially the secondary school principals to perform supervision more effectively. The Islamic Education Department of MOE and YIK may also use the findings of this study to help school principals improving the supervisory practices in the school to produce more quality school that will be reflected as the catalyst for national education transformation.

\section{Method}

The research design of this study is quantitative form which is a method of study using questionnaire and involving measurement of research variables through statistical description (Ghazali \& Sufean, 2016). Generally, this study is in the form of a survey using cross sectional method (Othman Talib, 2016) in the quantitative data collection process through the questionnaire answered by the respondents. The target population in this study was 85 secondary religious 
secondary schools under the supervision of YIK. The number of teachers serving in 85 of YIK Religious School is 2,678 people and from the total, 1,548 people are female teachers and 1,130 people are male teachers (YIK, 2017).

Study samples were made up of 360 male and female teachers of YIK Religious Secondary School located in the urban and rural areas of Kelantan. The teachers served in three categories of YIK Religious Secondary Schools namely Maahad, Sekolah Menengah Agama (SMUA) and Sekolah Menengah Agama Bantuan Kerajaan (SABK). The selection of 360 teachers from 2,678 people was based on sample size recommended by Krecjie and Morgan (1970). The type of probability sampling procedure used in this study is the cluster sampling procedure. The selection of this procedure is based on studies performed on large populations (Chua, 2014) involving the entire state of Kelantan. The researcher has randomly selected teachers from 85 schools based on Maahad, SMUA and SABK categories which are located and scattered throughout Kelantan state, Malaysia. The selection of samples was using stratified sampling method based on the provision of rating method according to the population strata to ensure that samples represented all religious schools in the study population. The proportional allocation count was done by multiplying the total number of school population by category (Maahad : 1,335 teachers, SMU(A) : 819 teachers and SABK : 524 teachers) with an estimated sample size of 360 respondents divided by the total population of 2,678 teachers. Thus, the total number of schools selected was 36 , while the number of teachers selected was 180 for Maahad category, 110 from SMU(A) category and 70 from SABK category.

Subsequently, schools in each category are further divided according to the location of schools i.e. urban and rural areas. The Maahad urban areas involving 90 teachers respectively, while SMU(A) urban areas involving 50 and 60 teachers respectively and SABK urban and rural areas involving 30 and 40 teachers respectively. The division of male and female gender is equal based on the number of respondents per school. The total of questionnaires distributed was 450 sets.

Overall, the return rate for the set of questionnaires was 84.88 per cent, a total of 382 sets of questionnaires from 450 sets of questionnaires distributed. Of the total 382 sets of questionnaires returned, a total of 360 complete sets of questionnaires were filled, while another 21 sets were incomplete and cannot be used for analysis purposes.

The respondents who had been involved in responding the questionnaires were 164 male teachers equivalent to 45.60 percent of the total respondents. Meanwhile, 196 respondents equivalent to 54.40 percent were female teachers. The respondents who had been involved in responding were made up of 162 teachers serving in urban area schools equivalent to 45.00 percent. Meanwhile, 198 respondents equivalent to 55.00 percent were teachers serving in rural areas schools. Out of 360, majority of the respondents graduated with Diploma in Education which comprised of 179 people equivalent to 49.70 percent. Subsequently, the respondents with the approval of the Education Degree of Education at 98 people equivalent to 27.20 percent. Meanwhile, 72 people equivalent to 20.00 percent of respondents obtained others (other professional certificate) and only eleven persons equivalent to 3.10 percent of respondents who obtained The Special Teacher's Certificate. 
The data collected in the research is analyzed through descriptive and inference method using Statistical Package for the Social Sciences (SPSS) software version 2.0. The quantitative data analysis is divided into two parts, namely normality test and verification factor analysis.

Meanwhile, a survey instrument is an instrument used to examine two variables of study which is the instructional supervision (independent variable) and teachers' quality (dependent variable). The research instruments have been compiled based on the appropriateness and ability to evaluate the variables involved in accordance with the 'Likert' scale. The instruments used in this study consist of three parts, namely Part A, Part B and Part C. Part A is a background and professional background of the respondent. While Part B is school principals' instructional supervision questionnaire and Part C consists of teachers' quality questionnaire.

The validity and reliability of the research instrument was certified by the education management academicians as recommended by Creswell (2014). This review is important in eliminating any discrepancies of concepts or errors in the instrument. This professional review helps the researchers to refine the instrument to produce a questionnaire that has validity, reliability, appropriate to the research context and user-friendly. In this regard, the researcher used the Cronbach's Alpha method to test the internal reliability and consistency of the study instruments as recommended by Creswell (2014), Chua (2014), Fauzi et al., 2014) and Othman Talib (2016). Cronbach's Alpha method is an internal consistency measurement method between items that form the constructs (Fauzi et al., 2014). Based on the context of this study, reliability analysis refers to the Standard Kualiti Pendidikan Malaysia gelombang 2 (SKPMg2) instruments (JNJK, 2017) and the Standard Guru Malaysia (SGM) instruments (MOE), 2009).

Overall, the dimensions of the instructional supervision has a high alpha value based on the measurement of questionnaires that were implemented, $\alpha=$. 960. While the alpha value of the dimensions of the instructional supervision is, directive guidance $(\alpha=887)$, collective development $(\alpha=869)$, professional development $(\alpha=.872)$, curriculum development $(\alpha=.846)$ and action research guidance $(\alpha=$.909). While the results of the reliability analysis of the teachers quality instrument, overall, the teacher's quality dimension item showed high value i.e. $\alpha=990$. The alpha value of each teacher's quality dimension is also high; professional value practice $(\alpha=.976)$, knowledge and understanding $(\alpha=966)$ and teaching and learning implementation skills $(\alpha=$. 978).

\section{Result and Discussion}

The data obtained in the study was analysed through descriptive and inference method by using SPSS software version 2.0. The data analysis in this study involves two methods, namely descriptive statistical analysis and inferential statistical analysis. As the results of statistical data analysis carried out, the researcher found that the instructional supervision quality and practices at the YIK Religious Secondary Schools' principals are at a high level. The overall level of instructional supervision is $(\mathrm{M}=4.17, \mathrm{SP}=.51)$ and the teachers' quality level as a whole is $(\mathrm{M}=$ 4.33, SP =. 37). Based on the recommendation of Fauzi et al., (2014), this decision suggested that 
the instructional supervision practice of the of YIK Religious Secondary Schools' principals and teachers' quality is at a high level.

The level of school principals' instructional supervision is entirely reflected based on the mean score value as well as the standard deviation value resulting from the 360 respondents. As a whole, the number of the mean earned has given an overview of the degree instructional supervision of the principals in the YIK Religious Secondary Schools. While the mean value of each dimension of the instructional supervision is 3.96 (high level) for the directive guidance, 4.36 (high level) for collective development, 4.21 (high level) for professional development, 4.33 (high level) for the curriculum development and 4.04 (high level) for action research guidance. The results of analysis on the instructional supervision showed that the collective development dimension had the highest mean value $(\mathrm{M}=4.36, \mathrm{SP}=.47)$ followed by curriculum development dimension $(\mathrm{M}=4.33, \mathrm{SP}=$. 56), professional development dimension $(\mathrm{M}=4.21$, $\mathrm{SP}=1.09)$, action research guidance dimension $(\mathrm{M}=4.04, \mathrm{SP}=.59)$ and directive guidance dimension $(\mathrm{M}=3.96, \mathrm{SP}=.66)$. The overall descriptive finding analysis indicated the mean score of the five dimensions which is the dimension of directive guidance, collective development, professional development, curriculum development and action research guidance on YIK Religious Secondary School M = 4.17, SP =. 51). The results of the analysis test are shown as Table 3.

Table 3. Analysis Results of Instructional Supervision Levels

\begin{tabular}{|c|c|c|c|}
\hline No. & Dimension & Mean & SP \\
\hline 1. & Directive Guidance & 3.96 & .66 \\
\hline 2. & Collective Development & 4.36 & .47 \\
\hline 3. & Professional Development & 4.21 & 1.09 \\
\hline 4. & Curriculum Development & 4.33 & .56 \\
\hline 5. & Action Research Guidance & 4.04 & .59 \\
\hline & Overall & 4.17 & .51 \\
\hline
\end{tabular}

The quality of teachers based on analysis performed, the mean score for three dimensions i.e. the dimension of professional value practices, knowledge and understanding as well as teaching and learning implementation skills as a whole are at high level $(\mathrm{M}=4.33, \mathrm{SP}=.37)$. The mean value of each teacher's quality dimension is 4.34 (high levels) of the professional value practice dimensions, 4.34 (High level) for the dimension of knowledge and understanding, 4.32 (High level) for the dimension of teaching and learning implementation skills. The result of analytical analysis on quality of teachers showed the dimension of knowledge and understanding has the highest mean value $(\mathrm{M}=4.34, \mathrm{SP}=.40)$ followed by professional value practice dimension $(\mathrm{M}=4.34, \mathrm{SP}=.39)$ and teaching and learning implementation skills dimension $(\mathrm{M}=4.32, \mathrm{SP}=.40)$. The overall descriptive finding analysis indicated the mean score value for the quality of the YIK Religious Secondary Schoolswas at high level $(\mathrm{M}=4.33, \mathrm{SP}=.37)$. The results of the analysis test are shown as Table 4.

Table 4. Analysis Results of The Teachers' Quality Level

\begin{tabular}{clcc}
\hline No. & \multicolumn{1}{c}{ Dimension } & Mean & SP \\
\hline 1. & Professional Value Practice & 4.34 & .39 \\
2. & Knowledge and Understanding & 4.34 & .40
\end{tabular}


The influence of the school principals' instructional supervision on the quality of the multiple regression analysis has been used to see the influence of independent variable on the dependent variable that is, the influence of the instructional supervision on the teacher's quality. The analysis results have shown that the instructional supervision of YIK Religious Secondary School's principals contributed 57.1 per cent $(\mathrm{R} 2=571)$ to variance in the teachers' quality. While the principals' instructional supervision among significant teachers contributed $0.090[\beta=.090, \mathrm{t}=$ $3.249, \mathrm{p}>.05(.001)]$. In this regard, it is a significant in anticipation of the quality of teachers based on the principals' instructional supervision of YIK Religious Secondary Schools with a value of $F(2,357)=237.401, p<.05(.000)$. The result of this analysis clearly showed that there was a significant influence between the instructional supervision and teachers'quality of YIK Religious Secondary Schools. The results of the analysis test are shown as Table 5:

Table 5. Double-Regression Analysis on The Teachers' Quality

\begin{tabular}{ccccccccc}
\hline Model 1 & $\mathbf{R}$ & $\mathbf{R}^{2}$ & $\mathbf{F}$ & $\mathbf{B}$ & SE B & Beta & T & Sig. \\
\hline Constant & .756 & .571 & 237.401 & .990 & .156 & & 6.334 & .000 \\
Instructional Supervision & & & & .090 & .028 & .124 & 3.249 & .001 \\
\hline
\end{tabular}

*p<.05

This finding highlighted significant influence, indicating that high standards of principals' instructional supervision can affect the high level of teachers' quality, while the low level of instructional supervision will be able to define the low level of teachers' quality.

YIK Religious Secondary Schools' principals' instructional supervision practices had implemented an instructional supervision exercise to realize the aspirations towards the quality of teachers and students' achievement. This is in line with the Malaysia Education Blueprint (MEB) 2013-2025 which claims the sustainability of leadership practices that could translate the strategy of implementation to an action that can improve the quality of teachers as well as students' achievement and school development.

The support for the MEB 2013-2025 statement is a statement of Standard 1 instrument, Standard Kualiti Pendidikan Malaysia Gelombang 2 (SKPMg2). The school principal plays as a high-impact leader who able to mobilize and move the school members on an integrated basis (JNJK, 2017). The findings of this study are in line with the findings of Mohd Yusri and Aziz (2014), Mohd Izham et al., (2015) and Grace et al., (2018). The implementation of the optimal instructional supervision practices by principals, based on clear goals and intensive planning will assist the principals to develop schools and improve the quality of teachers' teaching and learning implementation (Nurahimah \& Rafisah, 2010; Hamdan \& Rahimah, 2011; Mohd Ibrahim, Mohammed Sani \& Rosemawati, 2015).

Furthermore, the school principals concerns on the development of the world's education and initiatives and their seriousness to organise programmes that can enhance the professionalism of 
teachers in a maximum and continuous basis will help them to improve the quality of teachers in schools. The need to have a high level of supervisory practice is also in line with the recommendation of the MEB 2013-2025 on empowerment and enforcement of the regulatory instructional supervision of schools' principals. Thus, the enforcement by the educational administration will increase the level of principals' instructional supervision practices. Besides, the educational administration is responsible to examine principals' supervision implementation according to the required standard (Nurahimah \& Rafisah, 2010;). Moswela, 2010; Tesfaw \& Hofman, 2012; Mohd Izham et al., 2013; Anike, 2015; Weerakoon, 2017; Grace et al., 2018). While the quality level of the teacher is $(\mathrm{M}=4.33, \mathrm{SP}=.37)$. Based on the recommendation of Fauzi et al., (2014) this decision suggests that the quality of teachers in school. The results of the study have shown that the independent variable can affect the quality of the teachers significantly.

It also shows that the presence of a high-level instructional supervision would improve the quality of the teachers' performance. The results then show that all dimensions of the instructional supervision, namely directive guidance, collective development, professional development, curriculum development and action research guidance influence the teachers' quality. However, the outcome of the analysis shows that the instructional supervision dimensions practiced by the principals were not standardized. The most widely practiced dimensions are collective development dimension followed by the curriculum development dimension, professional development dimension, the action research guidance dimension and the directive guidance dimension. The dimension of the directive guidance is the least practised dimension by YIK Religous Secondary Schools principals.

The inconsistencies of practicing the dimension of this instructional supervision is the reality that occurs among the principals of YIK Religous Secondary Schools. Hence, this issue should be given serious attention and appropriate action to improve the quality of the teacher and the quality of the country's education in line with the aspirations of the YIK and MEB 2013-2025 education philosophy. A quality, holistic and effective instructional supervision implemented by the principals is a factor that influences the improvement towards teachers' quality (Nurahimah \& Rafisah, 2010; Hamdan \& Rahimah, 2011; Arsaythamby \& Mary, 2013; Dangara, 2015; Norlela \& Mohd, 2015; Gloria et al., 2016; Habibah et al., 2016; Malunda et al., 2016; Grace et al., 2018). The findings of this study supported the Excellent School Instructional Supervision Model introduced by Glickman et. al., (2005). The instructional supervision is the implementation of the teaching leadership, something that develops and combine all elements of effectiveness to be integrated for the overall action in school (Glickman et al., 2005) as well as the boost of teachers' teaching performance improvements (Sullivan \& Glanz, 2000).

This factor explains that if the instructional supervision is armed with high knowledge, efficiency and skills and practiced effectively it will be able to enhance its quality and improve school performance which is the catalyst for the sustainability of education. This is a reflection of the principals' skills of implementing the duties has been identified as success principals to elevate the quality of the teacher. Skills can be generated through various leadership exercises. In addition, the role and commitment of the teachers became very challenging (Saedah Siraj \& Mohammed Sani Ibrahim, 2016) with the need of the 21 st-century education as the objective was to produce world level, progressive, quality and competitive students. 
A quality teacher willing to face challenges to MOE to realise the transformation of education (MEB 2013-2025). Therefore, it is very important for teachers to prepare themselves with teaching and learning skills before implementing an effective lesson (Wan Noor Adzmin \& Suria, 2017). While school principals should make effort to change leadership practices including the management of the decision to achieve the performance index (KPI) set by MOE in MEB 20132025 (Wan Noor Adzmin \& Suria, 2017). Hence, the instructional supervision of principals should be embedded from the objectives of implementation, effectiveness of implementation and uniformity of the performance of a dimensional supervision. To achieve this, the action should be taken by the MOE and State Education Department (SED) authorities, in particular for the standardisation of the regulatory supervision practices, the injection of principal's supervisory skills and audit actions by educational management for the review and balance of supervision practices.

The findings of the study showed that The Excellent School Instructional Supervision Model and Malaysian Teachers Standard Model were in line with the government's aspiration to improve the quality of Malaysian teachers, thereby boosting the quality of Malaysian education equivalent to international education. This study also contributes to the theories used as the main framework for this study. The excellent school theory predicted that the supervisory supervision of the aspect of the field guidance, professional development, collective development, curriculum development and action research guidance will affect the improvement of teachers' quality in religious secondary schools.

\section{Conclusions}

This study contributes significantly to the proliferation of knowledge in the field of education management. The supervision has a strong potential to be the main contributor to the teachers' quality. Although the level of supervisory practice is high, there is a slight difference from the frequency of practicing the supervisory dimensions among principals. The most common dimension practiced is collective development dimension while the most uncommon dimension practiced is directive guidance dimension.

The inconsistencies of practicing the dimensions of the supervisory supervision should be given serious attention and appropriate action to ensure the adoption of the supervisory supervision to maintain the quality of the teachers at the same time improve the quality of education. The systematic mechanisms and best practices suggested by the researcher should be applied to the school principals. In addition, the recommendations of the empowerment of the audit enforcement authorities on the principals' supervisory practices should also be given serious attention and appropriate action.

In addition, a teacher's accountability is yet to be adequate with supervision only until is corroborated with skills included value of teaching professionalism, knowledge and understanding as well as teaching and learning performance skills. Without such skills, it is impossible that the teaching and learning performance can be improved as to realise the 21st-century learning techniques (PAK-21). Since teachers' challenge is to pursue a quality, global, competitive and international educational continuity as well as the rapid development of technology, then 
accordingly teachers at YIK Religous Seconcary Schools be exposed to continuous training based on the needs throughout the services.

In this regard, the findings of this study should be a source of information that will help the authorities and stakeholders to streamline the principal assignment as the main supervisor in the school. The merit of supervisory skills should be a key aspect for the appointment of an individual as a principal. While the principal performance is not only on the qualifications that are appointed and placed in a school, but also emphasis on the guidelines and standardization of tasks and a systematic balance of revision by the authorities in the Education Department.

This study also contributes to information that is beneficial to educational administration management to formulate a more strategic and systematic planning to standardise the adoption of the supervisory supervision, strengthening professional value and thus enhancing the quality of teachers. This research has contributed to the highest quality improvement in the management and teacher's quality.

\section{References}

Anike, S. M. (2015). Instructional supervisory practices and teachers' role effectiveness in public schools in Calabar South Local. Journal of Education and Practice, 6 (23).

Arsaythamby Veloo \& Mary Macdalena Komuji. (2013). Kesan penyeliaan klinikal terhadap prestasi pengajaran guru sekolah menengah. (The effects of clinical supervision on the teaching performance of secondary school teachers). Asia Pacific Journal of Educators and Education. 28, 81-102.

Bahagian Pendidikan Guru. (2009). Standard guru Malaysia. Putrajaya: Kementerian Pendidikan Malaysia.

Bahagian Pendidikan Guru. (2016). Dokumen awal pelan induk pembangunan profesionalisme keguruan. Putrajaya : Kementerian Pendidikan Malaysia.

Chua Yan Piaw. (2014). Kaedah penyelidikan. Selangor: Mc Graw-Hill Education Sdn. Bhd.

Cresswell, J. W. (4 ${ }^{\text {th }}$ ed.). (2014). Educational research: Planning, conducting and evaluating quantitative and qualitative research. Pearson New International edition. Harlow, Essex: Pearson Education Limited.

Dangara, U. Y. (2015). The impact of instructional supervision of teacher effectiveness on secondary school in Nigeria. International Journal of Advanced Research. 3(3), 12-16.

Danielle Foong Chai Yen \& Mohd Khairuddin Abdullah@Jerry. (2017). Analisis perbandingan kepimpinan instruksional pengetua dan kepuasan kerja guru. International Journal of Education, Psychology and Counsel. 2(5), 318-339.

Esia, D. K., \& Baffoe, S. (2018). Instructional supervisory of head teachers and teacher motivation in public basic school in Anomabo education circuit. Journal of Education and e-Learning Research. 5 (1), DOI: 10. 20448, 43-50.

Fauzi Hussin, Jamal Ali \& Mohd Saifoul Zamzuri Noor. (2014). Kaedah penyelidikan dan analisis data SPSS. Sintok: Universiti Utara Malaysia. 
Ghazali Darussalam \& Sufean Hussin. (2016). Metodologi penyelidikan dalam pendidikan: Amalan dan analisis kajian. Kuala Lumpur: Universiti Malaya.

Gloria, I. N., Eziamaka \& Nonye, E. (2016). The impact of instructional supervision on academic performance of secondary school students in Nasarawa State, Nigeria.

Goe, L. (2007). The link between teacher quality and student outcomes: A research synthesis. Washington DC: National Comprehensive Center for Teacher Quality. Retrieved from http://www.ncctq.org.

Grace, A., Anyango, Francis, I., Tonny, O. O. (2018). Influence of type of instructional supervision on teaching effectiveness in English in secondary school of Kakamega Country, Kenya. International Journal of Social Science and Humanities Research. 6 (3), 777-784.

Hamdan Said \& Rahimah Abdul Rasid. (2011). Amalan penyeliaan pengajaran dan pembelajaran di sekolah-sekolah kebangsaan di Daerah Melaka Tengah, 1-9.

Kementerian Pendidikan Malaysia. (2012). Pelan pembangunan pendidikan Malaysia (PPPM) 2013-2025. Putra Jaya : Kementerian Pendidikan Malaysia.

Krejcie, R. V. \& Dayle, W. Morgan. (1970). Determining sample size for research activities. Educational \& Psychological Measurement. 30, 607-610.

Laporan Tahunan 2017. (2018). Pelan pembangunan pendidikan Malaysia 2013-2025. Putrajaya : Kementerian Pendidikan Malaysia. Retrieved from http://www.moe.gov.my.

Lilia Halim, Nor Aishah Buang \& T. Subahan Meerah. (2010). Action research as instructional supervision: Impact on the professional development of university based supervisors and science student teachers. Procedia Social and Behavioral Sciences 2. 2868-2871. Retrieved from http://www.sciencedirect.com.

Malunda, P., Oven, D., Musaazi, C. S., \& Oonyu, J. (2016). Instructional supervision and the pedagogical of secondary school teachers in Uganda. Journal of Education and Practice. 7 (30), 177-187.

Mohd Izham Mohd Hamzah, Yan Wei, Jamil Ahmad, Aida Hanim A. Hamid \& Azlin Norhaini Mansor. (2013). Supervision practices and teachers' satisfaction in public secondary schools: Malaysia and China. International Education Studies. 6 (8), 92-97.

Mohd Yusri Ibrahim \& Aziz Amin. (2014). Model kepimpinan pengajaran pengetua dan kompetensi pengajaran guru. Jurnal Kurikulum dan Pengajaran Asia Pasifik. 2 (1), 11-22.

Moswela, B. (2010). Instructional supervision in Botswana secondary schools: An investigation. Educational Management Administration \& Leadership SAGE Publications. 38(1), DOI: $10.1177,71-87$.

Muhammad Faizal A. Ghani \& Abd. Khalil Adnan. (2015). Model program perkembangan profesionalisme guru Malaysia: Satu kajian keperluan di sekolah berprestasi tinggi dan sekolah berprestasi rendah. Jurnal Kepimpinan Pendidikan. 2(2), 1-16. Retrieved from http://e-journal.um.edu.my/publish/JuPiDi/. 
Norlela Ali \& Mohd Munaim Mahmud. (2015). Pengaruh kualiti penyeliaan pengajaran dan pembelajaran ke atas efikasi guru. Kuala Lumpur: Institut Kampus Ilmu Khas.

Nur Mustafa, M., \& Norasmah Othman. (2011). Latihan dalam perkhidmatan bagi meningkatkan kualiti pendidikan guru di Pekanbaru Riau, Indonesia. Jurnal Pendidikan Malaysia. 36(2), $19-24$.

Nurahimah Mohd Yusoff \& Rafisah Osman. (2010). Hubungan kualiti penyeliaan pengajaran dan pembelajaran di bilik darjah dengan efikasi guru (The relationship between quality teaching and learning supervision with teachers' efficacy). Asia Pacific Journal of Educators and Education. 25, 53-71.

Othman Talib. (2016). Asas penulisan tesis penyelidikan dan statistik. Selangor: Universiti Putra Malaysia.

Saedah Siraj \& Mohammed Sani Ibrahim. (2016). Standard kompetensi guru Malaysia. Universiti Malaya. Kuala Lumpur : Fakulti Pendidikan

Samoei, C. J. (2014). Instructional supervisory role of principals and its influence on students' academic achievement in public secondary school in Nandi North District Nandy Country Kenya (Master's thesis). Africa: University of Eastern Africa.

Sullivan, S., \& Glanz, J. (2000). Supervision that improves teaching. Thousand Oaks: Crowin Press.

Tesfaw, T. A., \& Hofman, R. H. (2012). Instructional supervision and its relationship with professional development: Perception of private and government secondary school teachers in Addis Ababa. (Master's thesis). Faculty of Social Sciences, University of Groningen.

Wan Noor Adzmin Mohd Sabri \& Suria Baba. (2017). Amalan kepemimpinan kolaboratif dalam kalangan pemimpin instruksional di sekolah rendah, Jurnal Kepimpinan Pendidikan. 4 (3), $1-16$.

Weerakoon, W. M. S. (2017). School based instructional supervision process issues by supervision teachers. Conference Paper: Sri Lanka,1-5.

Yayasan Islam Kelantan. (2015). Pelan Strategik Yayasan Islam Kelantan 2016-2020. Kelantan: YIK.

Yayasan Islam Kelantan. (2017). Laporan Tahunan YIK 2017. Kelantan: YIK. 